\title{
Disciplinary Evolution and the Rise of the Transdiscipline
}

\author{
Eli B. Cohen \\ Informing Science Institute \\ Santa Rosa, CA, USA
}

EliCohen@InformingScience.org

\author{
Scott J. Lloyd \\ University of Rhode Island \\ Kingston, RI, USA
}

\section{sjlloyd@mail.uri.edu}

"In science ..., novelty emerges only with difficulty, manifested by resistance, against a background provided by expectations."-Thomas Kuhn (2012)

\begin{abstract}
This paper challenges readers to reflect on academic disciplines in a new way, through the lens of the theory of evolution. Indeed, how disciplines came into being has been largely left unexplored. This paper shows how the concepts of evolution can be productively applied to describe the development, creation, and diminishment of disciplines. These concepts include natural selection, speciation, parallel evolution, extinction, and heterosis, among others. The paper concludes that these forces lead to a prediction that a new form of organization, the transdiscipline, is evolving to become perhaps predominant.
\end{abstract}

Keywords: Informing Science, transdiscipline, academic disciplines, evolution

\section{Introduction}

\section{What is an Academic Discipline: Something Old, Something New}

The term academic (or scientific) discipline can be defined as academic studies that focus on a self-imposed limited field of knowledge. The idea of scientific disciplines is both old and new. Dirks (1996) traces the origins of academic disciplines back to the ancient Greeks, around 500 BCE, but writes that university departments were first seen in the US only around 1825 . Stichweh (2001) also sees scientific disciplines as a relatively new phenomenon, writing "The scientific discipline as the primary unit of internal differentiation of science is an invention of

Material published as part of this publication, either on-line or in print, is copyrighted by the Informing Science Institute. Permission to make digital or paper copy of part or all of these works for personal or classroom use is granted without fee provided that the copies are not made or distributed for profit or commercial advantage AND that copies 1) bear this notice in full and 2) give the full citation on the first page. It is permissible to abstract these works so long as credit is given. To copy in all other cases or to republish or to post on a server or to redistribute to lists requires specific permission and payment of a fee. Contact Publisher@,InformingScience.org to request redistribution permission.

nineteenth century society."

\section{How do academic disciplines differ?}

Disciplines differ from one another in at least three primary ways: the area of their investigations (which we call context), their research methods, and their epistemologies (Schommer-Aikins, Duell, \& Barker, 2003). The contexts of 
disciplines are often rendered and compared using a system created by Biglan (1973a, 1973b) that posits a classification of academic disciplines on three orthogonal dimensions (hard vs. soft disciplines, pure vs. applied disciplines, life vs. non-life context). Figure 1 displays in two-dimensions the essence of this framework.

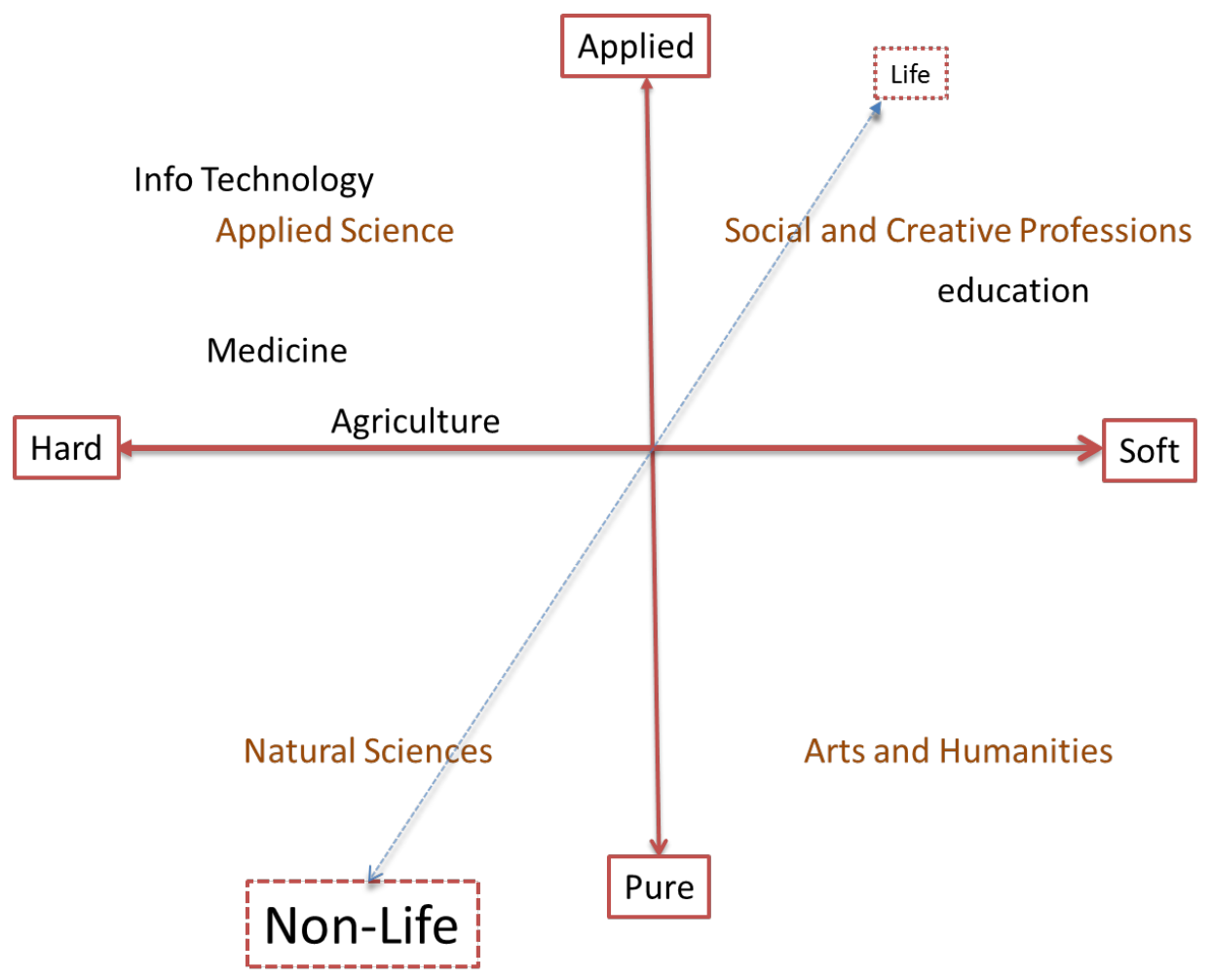

Figure 1. Biglan organized disciplines across three dimensions, as shown, based on their epistemologies, applicability, and focus on living or never living artifacts. (Adapted from Biglan, 1973a, 1973b)

\section{The Theory of Evolution in Brief}

The theory of evolution was developed to aid understanding of changes in life forms over generations. Some of the major themes of the theory include the following (see for example, "Introduction to evolution," n.d.; Welcome to evolution 101!, 2014.):

- Heredity: the defining materials delivered from generation to generation

- Variation including:

- Natural Selection (non-random and gradual process of natural variation ) and

- Mutation, changes in an organism's hereditary information

$\circ$ Drift (random change in the genetic variation of a population from generation to generation)

- Speciation: the process in which a species diverges into two or more descendant species.

- Extinction

- Parallel Evolution: the phenomenon of distinct species that evolved independently possessing similar traits.

- Heterosis: improved fitness on an evolutionary fitness landscape of a hybrid offspring. 


\section{Can Evolution Theory Improve Our Understanding of Disciplines?}

This paper contends that the analogy between biological evolution and disciplinary evolution is revealing and, so, useful. While it is useful, the analog breaks down when applied at the detailed level.

First, evolution theory deals with changes to life forms, and disciplines are not life forms. The paper argues that, like life forms, academic disciplines change over time and these changes occur in ways similar to how life forms change. That is, this paper has as its premise that many of these themes of evolution theory have explanatory power when applied to understanding how the current academic disciplines came into being and to anticipate what is in store for the future of disciplines. As with biological forms of life, academic disciplines evolve in response to environmental changes and interactions with others. Those that adapt to their present environment flourish and become stronger; those that do not wither and disappear. Rapid environmental changes can lead to the extinction of those organisms that cannot adapt.

Second, the analogy breaks down in that biological evolution typically (but not always) involves the mixing of genetic material from two donors of the same (or similar) species. In disciplinary research, it is common that research is conducted by any number of researchers in that discipline, all sharing their thoughts and work.

Third, when we deal later in this paper with heterosis, in biology the parent species must have great genetic similarity. In disciplinary heterosis, the parent disciplines may be greatly dissimilar and that dissimilarity adds to the vigor of the offspring.

So while evolution as studied in biology is not perfectly analogous with disciplinary evolution, the authors feel that the conclusion that emerges from this study are compelling: focusing solely on intra-disciplinary research hobbles and limits advances in science. Many, if not most, of modern advances in science involve discoveries that cross traditional disciplinary boundaries.

While fuller exploration of the evolutionary points might make the paper more substantial, the authors feel that those explorations are unnecessary (and might actually reduce the impact of the article).

\section{Disciplinary Heredity: What is inheritable "genetic" material when applied to disciplines?}

As mentioned above, disciplines differ not just in their area of investigation (their context), but also in terms of their research methods and their epistemologies (Schommer-Aikins et al., 2003). Similarly, Dirks (1996) writes, "By common understanding, 'discipline' in an academic sense pertains to the practice of study of a certain category of experience, its methodologies, how it goes about its pursuit of truth."

Viewing these terms from the lens of the Theory of Evolution, each discipline has its own defining traits - sets of key knowledge, methods, and assumptions - passed on via teaching and research that separate it from other disciplines. This selection of context and methods form the "genetic material" of each discipline.

In the following section, we discover how the concepts of evolution can show how select disciplines came into their present state. 


\section{Early Evolution of Selected Disciplines}

According to Michael McKeon (1994, p. 25, cited in Dirks, 1996), the issue of how academic disciplines came into being and change has largely gone unexamined. He points out, "Our familiar disciplines have secret histories, their apparently monolithic integrity sometimes obscuring a radically disparate and interdisciplinary core."

To illustrate its premise, this paper briefly explores the development of a few selected disciplines, showing how their histories can be viewed through an evolutionary lens. For reasons that will be clearer below, we start by examining the early evolution of disciplines (when few technologies were available) and then jump to a period before the industrial and information revolutions, and only then examine more recent evolutionary events in these disciplines in an environment possessing modern technologies..

The descriptions of selected disciplines are by design just broad-brush explorations of how specific disciplines evolved, without going into detail. Readers who wish to study changes in universities over long time frames may wish to examine the chronology of individual universities and their departments. For example, the chronology of the University of Bologna, the oldest university in Europe, can be found at http://www.unibo.it/en/university/who-we-are/ourhistory/university-from-12th-to-18th-century . More discipline specific time lines are also available, such as the history of the Department of Education at Oxford at http://www.education.ox.ac.uk/about-us/timeline-history/ We leave those studies to trained historians.

The sections below show disciplinary evolution via natural selection, speciation, extinction, parallel evolution, and conclude with a discussion of heterosis.

\section{Natural Selection and Mutation}

Let us begin the argument that it is worthwhile viewing disciplines and how they develop through the lens of evolution by looking at agriculture. We continue this introduction looking at education, medicine, and library science.

\section{Agriculture (prior to agribusiness)}

Natural selection is the gradual process by which helpful traits become more common and unhelpful traits become less common in a population.

According to Wikipedia ("Agriculture," n.d.), for most of human history, from prior to the industrial revolution around 250 years ago, the occupation most prevalent by far was in subsistence agriculture with people raising crops for their own consumption. Farming may have started as early as 13,000 years ago at the end of the last ice age.

The earliest records of recorded history are from Sumeria in the Uruk period around 5300 BCE and deal with crop yields. Later, Roman literature mentions crop rotation methods. Agricultural practices such as irrigation, crop rotation, fertilizers, and pesticides were developed long ago. Yet advances in their use in prior centuries, the years we now writing about in this section, pale when compared with recent developments. Recent advances are covered later in this paper to help our discovery of an evolutionary process other than natural selection.

The point here is that while farming methods changed slowly, farmers who practiced irrigation, crop rotation, and the use of fertilizers and pesticides dominated over farmers who lacked these practices. The discipline of agriculture evolved to include these successful farm practices while practices that did not lead to success (such as human sacrifice to bring rain or continually growing the same crop in a field) became less prevalent. 
As we shall see below, all this changed during modernity, principally through integration with various sciences and technologies.

\section{Education of children (prior to the current information revolution)}

We can at best speculate that prior to written history children were educated similarly to how now happens in preliterate societies, that is by elders demonstrating and children imitating. "Traditional knowledge were (sic) expressed through stories, legends, folklore, rituals, and songs, without the need for a writing system. Tools to aid this process include poetic devices such as rhyme and alliteration" ("History of Education," n.d.). Note that even today, the total education of children into society, which includes not only schooling but also education by parents and peers, still uses these non-written methods.

The history of education is commonly said to have begun with the Greeks, particularly Socrates (469 BCE - 399 BCE) and the Socratic Method of teaching. The child was thought either to have been born with a blank slate (Tabula rasa) or to be born with a mind that pre-existed birth in the heavens. Contrary to the modern views on children, for most of history the young learner was considered to be an ignorant, even stupid little adult and treated and educated accordingly.

Throughout most civilizations, formal literate education of children was limited to the nobility and aristocrats and thought of as a luxury. Typically the education of children was organized around religion or the military.

All this changed in the 1700's with the modern study of education. (One could view this as a mutation of the previous "genetic" material of education of children.) That change can be characterized through the works of two of the founders of modern education, Pestalozzi and Fröbel.

Johann Heinrich Pestalozzi (1746 -1827) developed the idea to teach to the child as a whole person. His book "How Gertrude Teaches her Children" explored how people thought about children and how to teach them (Green, 1905). Essentially Pestalozzi viewed children as we now do (rather than as little adults) and wrote that teaching should focus on their specific needs. Friedrich Fröbel (1782-1852), a student of Pestalozzi, developed the idea of learning through games and devices.

Once again, all this changed during modernity, principally through integration with information technologies. Throughout this paper we shall be repeating this point of disciplines changing in response to technology.

\section{Medicine (prior to modernity)}

According to "History of surgery" (n.d.), archaeological and anthropological studies as early as the Mesolithic times dated to approximately 12000 BCE show pre-historic evidence of surgery. Already in the times of ancient Egypt (around 5000 years ago), a system of medicine existed including medical examination, diagnosis, and prognosis. Studies of the anatomy improved surgery, but progress in surgery awaited two developments.

Mutation. The American Heritage Medical Dictionary defines mutation as "a sudden structural change within a gene or chromosome of an organism resulting in the creation of a new character or trait not found in the parental type" ("Mutation," 2008). Changes in the conduct of medicine (in the West, at least) were gradual, up until two events that radically changed the conduct of medicine. The two events that medicine (once adopted) changed the conduct of medicine in radical ways were (1) the discovery of antiseptics (along with the development of germ theory) and (2) the innovation of anesthesia. Atul Gawande (2012) writes in the New England Journal of Medicine that the birth of modern surgery began with the invention of anesthesia and the adoption of antiseptic practices. The development of germ theory of disease in the $19^{\text {th }}$ century 
changed not just surgery, but how the entirety of medicine was practiced ("Ether Anesthesia", n.d.). Through these and perhaps other "mutations", medicine in the West was practiced with little change from outside influences prior to the last half-century.

Here too, all this changed in recent years, principally through medicine's integration with information and other technologies.

The early history of agriculture and medicine are two example disciplines that changed little prior to the availability of modern technologies. The needs of society changed little. In contrast, library science evolved in light of changing societal needs.

\section{Library science (prior to information science)}

One can well argue that Library Science throughout the ages evolved from the actual conduct of what librarians do. Here in brief are the earliest occupations that perform tasks now seen as part of Library Science ("Library," n.d.).

Storage and Retrieval. Perhaps the earliest precursor to the modern librarian can be found in the "Keepers of the Records" of Sumeria in the Uruk period (around 5300 BCE). Their role was that of Custodian. The land's records were valuable and the profession evolved to keep them safe.

Classification. The task of organizing knowledge can be traced to the Assyrians and Egyptians. The Assyrians, like the earlier Sumerians, were located in Mesopotamia. These predecessors of the librarians had the job of organizing records, arranging them in logical order, and cataloging the records by subject or type, providing each one with a tag that identified it.

Librarianship in Europe can be traced to the Middle Ages when librarianship was needed not only to store, classify, and retrieve, but also to replicate manuscripts (and oversee their safety) in Scriptoria. The scriptorium is the predecessor of university (as well as, to a limited extent, Printon-Demand publishing).

Dissemination of Information to the Public. The French Revolution in Europe (1789-1799) added a new role that was filled by librarians, that of ensuring that information once stored could be retrieved for the nation, according to A. K. Mukherjee (as cited in Alkan, 2008), and ultimately in providing modern library services available to the general public, regardless of wealth or education.

Modern Librarianship. The role of guide to researchers, indeed the role of the modern reference librarian, can be traced to the work of the American Melvil Dewey (1851 -1931).

As above, the discipline developed to meet the (changing) needs of society. And all this changed during modernity, principally through integration with information technologies.

\section{Speciation}

So far we have looked at how natural selection and mutation can describe some changes in disciplines. We now examine the explanatory power of speciation.

Speciation here refers to formation of new disciplines, usually by the division of a single discipline into two or more "genetically" similar but distinct ones. Disciplinary Speciation erupted during the last century. Here are some new disciplines and sub-disciplines that have emerging in the past fifty years:

Agriculture: Purdue University Agriculture school website (Purdue University, 2012) now lists graduate specialties, including the following: 
- Agronomy,

- Animal Sciences,

- Botany,

- Food Science,

- Forestry \& Natural Resources,

- Horticulture \& Landscape Architecture, and

- Youth Development \& Ag Education, to name a few

Education: Similarly, the discipline of education developed specialized subdisciplines in early childhood education and adult education (each focusing on issues of a particular client), and these are just two of a large number of sub-disciplines. For example, Goucher College (2013) offers specialized graduate degrees in these specialties:

- Athletic Program Leadership and Administration

- At-Risk \& Diverse Learners

- Literacy Strategies for Content Learning

- Middle School Specialization (available only through Cohort program)

- Montessori Studies

- Reading Instruction (MSDE-approved for Reading Specialist certification)

- School Improvement Leadership (MSDE-approved program for Administrator 1 Certification)

- School Mediation (in redevelopment)

- Special Education for certified Elementary and Secondary Teachers

Medicine: The American Board of Medical Specialties (2013) notes that medicine now has well over 40 recognized specialties, from Anesthetics to Vascular surgery.

Business: Business itself has many subdisciplines, as seen at any university. More subdisciplines emerge each decade or so. Bird, Welsch, Astrachan, and Pistrui (2002) write of the development of Family Business Research out of Business Research. Sheth and Parvatiyar (2002) point out that relationship marketing is an emerging new discipline, developed out of marketing research.

BusinessWeek (Gloeckler, 2010) lists a number of business specialties, including the following:

- Accounting,

- Business Law,

- Business Ethics,

- Financial Management,

- Macroeconomics,

- Marketing,

- Microeconomics,
- Operations Management,

- Quantitative Methods,

- Strategy, and

- Sustainability

(and this list does not include other specialties, such as real estate).

The lists above for the various fields include only a selection of the new disciplines, the ones that can be identified with speciation or specialization within the existing discipline. Other new disciplines arose following a different process. Below, in the section on heterosis, we will show that other disciplines have come about as the result of combining different disciplines to come up new ways to understand reality. Also note that in later discussion we will explore the need not just for specialists, researchers who focus on specialized fields, but also for generalists, researchers with broader expertise. 
But before moving on, we discuss briefly two topics related to the opposite of disciplinary vigor: inbreeding and extinction.

\section{Inbreeding in Academia through Disciplinary Silos}

Inbreeding refers to results of pairing parents who share considerable genetic material. Inbreeding generally leads to a decrease in fitness.

Unlike industry, which encourages cross-disciplinary research and research teams, academic research in universities most commonly is conducted entirely within a discipline. This constriction, which we refer to as the disciplinary silo, is due to a reward structure that encourages researchers to limit their research agendas to topics that fall within the limited scope of their discipline.

\section{Fad Research Topics}

The artificial constriction (inbreeding) can lead to unnecessary repeated research on fad topics. For example, in the field of Information Systems, there have been almost 1,400 research papers published on the Technology Acceptance Model. This model postulates that people who think that they will benefit from technology are more likely to accept it, particularly if it is easy to use. While to an outsider, it may look like repeatedly replicating the research finding produces no new or useful information, to a researcher in IS whose reward structure is based on doing what others are accepting as valid research, it makes financial sense to write papers on this and other fad topics. In addition, inbreeding can lead to researchers holding myopic views of complex phenomena.

In the discussion section below, we discuss how current university reward systems for academic research have led to this inbreeding phenomenon.

\section{Extinction}

Some animal and plants that once existed no longer do, through the process known as extinction. For example, all but one member of the family Phascolarctidae have come to be extinct; only the koala remains extant. The koala eats primarily the leaves of eucalyptus trees. Should the gum tree become no more, so will the koala and so would end the entire family Phascolarctidae.

Unlike creatures (which can completely die out), knowledge never completely dies so there can be no complete extinction of knowledge. For example, the knowledge of how to construct buggy whips, once created never fully disappears. However, we can say that a discipline is on its way to becoming extinct when, because of waning interest, little or no new useful research in the discipline is conducted and published. In academia, another artifact of impending disciplinary extinction is declining numbers of students majoring in the discipline.

Secretarial/Business Education. One example of a discipline becoming extinct is secretarial education. Prior to the wide acceptance of personal business computers, Anderson (1962) wrote that secretarial education in the US had a bright future in shorthand and transcription. A quarter century later, Bennett (1988) warned that in the United Kingdom secretarial education needed to adapt if it was to stay relevant. Bennett writings were prescient. The need for shorthand and transcription is greatly reduced due to technological alternatives. And so the student demand for this major (or even elective courses) dropped sharply. For example our research found that Eastern Illinois University merged its Business Education department into its Management Information Systems department, all but eliminating Business Education. Similarly, the University of Nebraska has downgraded its major to a certificate program. As noted above, the use of shorthand in business in the US has all but disappeared as more and more executives use computers. And voice to text transcription, which at one time required a secretary, can now be accomplished 
by software (as the authors of this paper can attest.) With the decline in number of jobs comes the decline in student enrollment. The field of secretarial education failed to adapt.

Management Science. Grossman (2001) wrote about the substantial decline in the number of college students majoring in Management Science. Informal research conducted by the authors of this paper found that in several universities Management Science no longer exists as a separate major. In the early 2000s several schools dropped Management Science as a major because of the perception that American students lacked the required competence in high level mathematics (Grossman, 2001). While the discipline of Management Science cannot be considered extinct, societal demand for it as a separate discipline is waning.

Our take on the situation is that societal needs changed, but those teaching Management Science did not respond to these changes.

Management Information Systems. There is a similar trend decline in the discipline of (Management) Information Systems. Saunders and Lockridge (2011) ask if they are seeing the death of the MIS degree. Regan (2008, as cited in Saunders \& Lockridge, 2011) writes that as many as $75 \%$ of all MIS programs have been eliminated since its heyday of the last millennium. What forces are driving MIS to extinction?

The discipline of Management Information Systems developed in the 1950s to meet the demands created by two events:

- The formation of the modern corporation (circa 1890), which allowed the amassing of the capital needed to make the large investment required to purchase and run a computer system (Berle \& Means, 1968).

- The development (and thus the availability) of the modern computer as a commercial product affordable by large corporations.

The field of MIS came out of large corporations needing business-trained people to work with their mainframe computer. Up to the 1970s, all business computing was done on large computers that required trained people to run the systems.

Beginning in the early 1980s, personal computers (for business and for home) made computing available to workers beyond those employed in departments of information technology. IT departments no longer served as the sole source of the information storage, retrieval, and processing resource. At the same time, business became more reliant on fast access to information. However, university MIS academic departments were slow to respond to the changing needs of business.

Our take on the situation is that societal needs changed, but those teaching Management Information Systems are failing to respond to these changes. For the last decade and a half, the field of MIS has undergone a crisis in its identity. This was first pointed out by Cohen (1999) and later picked up by others (Alter, 2003; Benbasat \& Zmud 2003; Boland, Culnan, Gurbaxani, Krcmar, Robey, Iacono, \& Orlikowski et al. 2002 cited in Alter, 2003; Gill \& Bhattacherjee, 2009; Karahanna, Davis, Mukhopadhyay, Watson, \& Weber, 2003; Orlikowski \& Iacono, 2001; Weber, 2006). The discipline currently is producing research that has limited real world application (Saunders \& Lockridge, 2011). We predict that if it continues to fail to adapt, it too will go extinct.

\section{Is Extinction Inevitable?}

Krishnan (2009) points out three strategies for disciplines to survive:

1. Turning inward and strengthening boundaries,

2. Forming strategic alliances with stronger disciplines, and

3. Reconstituting the discipline in a newer and larger field of study. 
We can see all these strategies being advanced by MIS researchers. Gill and Bhattacherjee (2009) argue that Management Information Systems has lost track of its original purpose, i.e., to inform practitioners. They recommend that MIS should focus its research on areas related to the needs of practitioners.

In Cohen's "Ugly Duckling" paper (1999), he calls for MIS to form alliances to share solutions with other, stronger fields (such as education and information science) that also use information to inform their clientele.

The third strategy, of enlarging the discipline, started decades ago when Management Information Systems expanded beyond management to include the solving of all business problems for all business users. Many academic departments dropped the word "Management" from their name in favor of just "Information Systems". Alter (2003) called for "scrapping the IS silo" to expand to Systems in Organizations. Likewise Avison and Nandhakumar (1995) and Cecez-Kecmanovic (2000) call for expanding the discipline to encroach upon areas currently researched by other disciplines.

However, others (for example, van Gigch \& Le Moigne, 1989; van Gigch \& Pipino, 1986) see this solution as counterproductive. The problem is that the "genetic material", that is the research methods and traditions, of any given silo are simply too narrow and limiting. Van Gigch viewed MIS as part of some larger system that he called the Modern Inquiring System.

(It is worth noting that Computer Science a generation ago took and soon abandoned the approach of laying claim to larger and larger areas of science as theirs and theirs alone. Within academia, we observed at our universities departments of computer science attempting to lay sole claim to the teaching of computer music and computer art.)

Extinction occurs when disciplines fail to respond to changes in the environment. Another phenomenon, parallel evolution, occurs when changes in the environment lead two or more existing disciplines to create solutions to this environmental demand. The next section explores an example of such parallel evolutions.

\section{Parallel Evolutions for Information Science: both from library science and from computer science}

Parallel evolution is the independent evolution of similar traits in distinct species. It is seen when similar environmental pressures create two or more genetically unrelated or distantly-

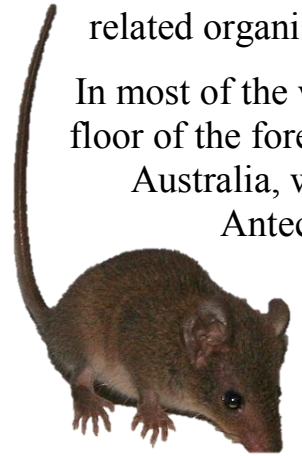

Figure 2. Antechinus - a non-rodent "mouse". Source: ("Antechinus," n.d.) parallel advancement from different disciplines in scientific theory.

The discipline of Information Science as seen on campus today appears to have two independent evolutionary origins: from either library science or from computer science. At the present, there are two distinct traditions that both claim to be authentic Information Science and that both lay claim to the same problem-set as their mission. To the evolutionary biologist, it comes as no surprise that nature can evolve solutions to a given problem from different sources. 


\section{Evolution of Library Science into Information Science}

According to Brookes (1980), the conduct of being a librarian changed around the time that the Internet was developed, when computers and Internet access became available. He writes that Information Science is a new and emerging discipline that emerged from the framework of library science. Brookes points out that Information Science should and does draw from philosophy (not technology). Brookes writes that the advances from Library Science to Information Science are due largely to its recognition that human knowledge is largely subjective. (This is in contrast to the origins of computer science, which started largely on the assumption that knowledge was objective.) While Library Science may have started with the concrete keeping of documents, it has evolved into a discipline entrenched in philosophy, echoes Alkan (2008).

Likewise T. D. Wilson (T. D. Wilson, 1981; see also T. D. Wilson, 1999, 2000) explores changing the focus of the library from repository to assistant for the person seeking information. Information Science, according to him, sees knowledge as more than simply objective. Wilson argues that the field of Information Science needs to appreciate subjective knowledge, such as human reaction to information. His goal was to redirect the focus from strictly on the organization and analysis of knowledge to also include information seeking behavior by people.

In summary, the evolutionary path from Library Science to Information Science kept the same philosophy of information and used the capabilities of computing and information technology better to achieve its goal.

\section{Another Path in Evolution: From a Branch of Computer Science to Information Science}

As noted above, the advent of computers and information technologies led to researchers trained in Library Sciences to evolve their field into the emerging discipline of Information Science to meet society's need for a better understanding of information as a topic of research. At the same time, researchers in the field of computer science worked to advance this same niche in science. Computer science researchers (principally in computational and mathematical computer science) added to their repertoire the study of biological, cognitive, and social aspects of computing. In 1957 the German computer scientist Karl Steinbuch coined the word Informatik. While there are differences in how the term Informatics is understood in Europe and in the Americas, the point here is that the focus of Informatics (as it developed from computer science) and Information Science (as it developed from Library Science) mostly overlap, and to the colleagues in other fields, the two views are all but indistinguishable. (To confuse things even further, some, principally in the US, use the term Informatics to refer to yet a different set of areas of study.)

Two paths to mostly the same discipline. To address the opportunities and demands from the Internet and computers, in the US and Canada, library scientists set about to add computer science concepts to their mix. In Western Europe, computer scientists were active in incorporating social science concepts, models, and research into their understanding of information processing. In both cases, the solution to meeting the expanding needs of the environment was to expand the discipline, or more properly, to develop a new discipline to meet society's need.

Schools of Information: i-Schools. As Library Science developed, universities responded by establishing "i-Schools" to deal with the growing number of interrelated areas being explored by the emerging discipline.

The site "Ischools" at http://ischools.org/directory lists, as of this writing, 46 universities that have "i-Schools". Most (40) appear to be full schools, colleges, or faculties, five are departments, and one is listed as an institute. From a quick analysis of the names of the i-Schools, $90 \%$ of the $\mathrm{i}$-schools that use a name signifying either library or computer science appears to have evolved 
from schools of Library Science (or archival science). While most use the term Information Science, Information Studies, or such, three use the term "media" in their name.

\section{Concept Transfer across Academic Fields - Heterosis and Hybrid Disciplines}

So far, we have seen how disciplines evolve through natural selection, mutation, speciation, and become extinct. We have noted parallel evolution. We now turn our attention to the development of new disciplines through the combining of other disciplines, a process called heterosis.

Heterosis refers to the improved fitness of hybrid offspring. For disciplines, this refers to the phenomenon that investigations drawing from the research beyond any one disciplinary silo are often superior to research that limits its scope to be entirely within a disciplinary silo.

For example, Bernard Luskin (1970) advanced computer assisted instruction and began to connect media and psychology into what is now the new field of media psychology. In 1998, the American Association of Psychology, Media Psychology Division 46 Task Force (Luskin \& Friedland, 1998) report on psychology and new technologies noted that the combination of media and communication as pictures, graphics, and sound increasingly dominates modern communication. Luskin also launched in 2002 the first degree programs in Media Studies and in Media Psychology, according to "Media Psychology" (n.d.).

The Social Psychology of Communication (Hook, Franks, \& Bauer, 2011) is the first comprehensive introduction to social psychological perspectives on communication, according to "Models of Communication" (n.d.). This accessible guide provides an overview of key theoretical approaches from a variety of different disciplines (including cognitive, developmental, and evolutionary psychology) as well as practical guidance on how to implement communication interventions in differing contexts.

New technologies affect, impact, and enable expansions of perhaps most existing disciplines. Eventually universities respond by changing their catalogs of course offerings in response to changes in the disciplines. This artifact allows us to track how the addition of "technology genetics" improves the fitness of existing disciplines. We can see this by tracking the use of lasers, a technology that has been around for more than half a century. By examining course catalogs, the authors found course-work involving lasers in the following university disciplines (among others):

- Physics

- Chemistry

- Electrical Engineering

- Civil Engineering

- Optical Surgery

- Dentistry

\section{Hybrid Disciplines}

We already mentioned the social psychology of communications as a hybrid discipline. It combines theories of media studies and psychology, including, for example, theories of persuasion, attention, and color ("New Media Studies," n.d.)

Silka (2013) writes about the great benefit of using frameworks and models created in other fields in the search for solutions to knotty problems. Silka's paper extols the benefit of reframing a problem commonly studied in one field alone as a problem of another field. For example, by 
viewing violent criminal behavior as a public health issue, the public health tools of epidemiology and intervention analysis can shed new light on the problem.

This paper started with a look at the evolution of agriculture, education, and medicine, ignoring recent history. Let us now look at how in recent years these disciplines have improved due to heterosis.

Blending Multiple Technologies into Agriculture: Large Scale Farming. For millennia, most agriculture was subsistence, with little produced beyond what the farmer consumed or traded for needed goods. In recent years, relying on economies of scale and the latest technologies, Large Scale Farming techniques enable large amount of food to be farmed at relatively low cost ("Large-Scale Agriculture," n.d.) Some of the latest advances in technology, some of which are only a decade old, include the use of global positioning satellites to analyze and record the yield of every row down to 3 feet resolution. This information is then fed into the various machines that a farmer uses to individualize yard by yard the most cost effective use of chemicals. For example, when spraying fertilizer the sprayer turns off individual nozzles, which affects only one six foot section of an individual row of crops. When harvesting the crop, the combine ( a machine used to harvest corn, soy beans, and other types of crop) records the yield for each six foot section of a particular row using GPS coordinates to mark the output of all the farmers' fields. The farmer can use this information to improve the crop yield/chemical use mix, thus both saving the farmer money and also reducing the amount of chemicals used by the farmer to grow a crop (Nemenyi, Mesterhazi, Pecze, \& Stépán, 2003)

In summary, agriculture has evolved to include now the use of GPS, satellite imaging, mechanization, soil chemistry, genetic technologies of seeds, and risk management. For example, one option in farming is to use genetically modified seeds that yield plants needing less water and are immune to the effects of Glyphosate (know commercially as "Roundup" herbicide). This enables the farmer simply to spray crops with Glyphosate and only the weeds but not the genetically modified corn and soy beans die.

Blending Psychology and Technology into Education. Research into education as an academic area of study took off in the past 60 years through the external contributions of two research streams: psychology and technology. Indeed these two streams are related. Two of the oft-cited fathers of the field of instructional theory are Benjamin Bloom in 1956 and Robert M. Gagne in 1965. Both Bloom and Gagne were trained, not in education, but as psychologists.

Blending Imaging Technologies into Medicine. The last 20 years brought to life the development of medical imaging technologies, the merger of computer science, medicine, physics, and associated technologies. These developments include the CAT, MRI and PET scans, ultrasounds, and even a swallow-able "pill" camera that traverses the small colon, taking pictures of the gastrointestinal tract along the way, and transferring the pictures to an external monitor. For eye surgery and joint replacements typically use lasers and robots to assist the surgeon in performing operations. It is the combinations of various disciplines that have made these advances possible:

- Bioengineering

- Mechanical Engineering

- Surgical knowledge

- Robotics

\section{The Benefit to Each Discipline of Cross-disciplinary Perspectives}

This paper is one example of using a concept created in one field (in this case, evolutionary biology) as an aid to understanding lines of inquiry (in this case, how disciplines develop). 
Another example of how a concept created to develop one domain of study profoundly impacted other domains can be seen in the impact of the Shannon-Weaver model of communications created for the purpose of communicating an idea about electrical engineering equations. The mathematics of Claude Shannon's original (1948) research article are not readily understandable by the general public, but his book co-authored by Warren Weaver (Shannon \& Weaver, 1963) made the work accessible, particularly so through the diagram shown as Figure 3. The model has been applied in a large number of fields, including, to name just a few, social science fields of education (e.g., Wagner, 1994), psychology (e.g., Boholm, 2008), social science (e.g., Feather, 2002; Hayles, 2006), information science (Ma, 2012) and communications (e.g., Weiss, 1992). Indeed, Berlos used the diagram to expand the areas of research for the field of (human) communications (CommunicationTheory.org, n.d.). (See Figure 4, the SMCR Model.)

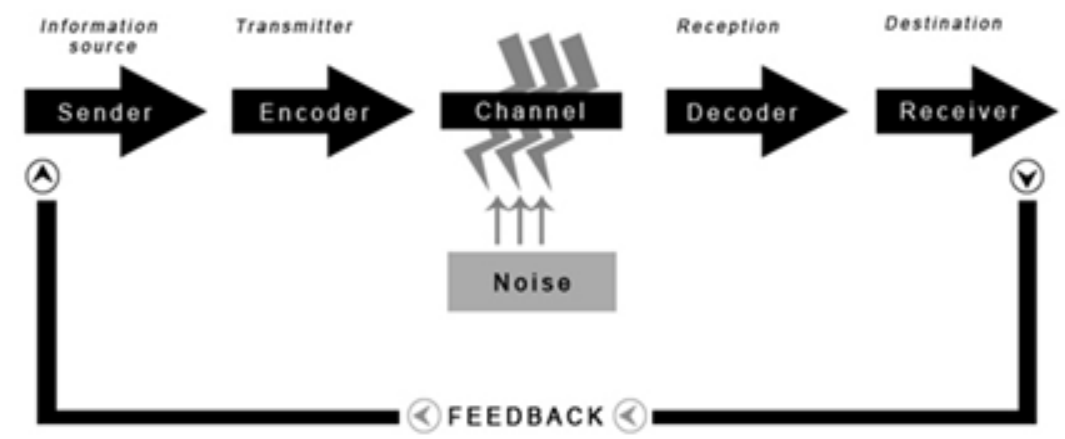

Figure 3. Shannon-Weaver Model of Communications

(Source: http://communicationtheory.org/shannon-and-weaver-model-of-communication)

\section{Berlos's SMCR Model of communication}

\begin{tabular}{|c|c|c|c|c|c|}
\hline Source & Encodes & Message & Channel & Decodes & Receiver \\
\hline $\begin{array}{c}\text { Communication } \\
\text { Skills }\end{array}$ & & Content & Hearing & & $\begin{array}{c}\text { Communication } \\
\text { Skills }\end{array}$ \\
\hline Attitudes & & Elements & Seeing & & Attitudes \\
\hline Knowledge & & Treatment & Touching & & Knowledge \\
\hline $\begin{array}{c}\text { Social } \\
\text { System } \\
\end{array}$ & & Structure & Smelling & & $\begin{array}{c}\text { Social } \\
\text { System } \\
\end{array}$ \\
\hline Culture & & Code & Tasting & & Culture \\
\hline
\end{tabular}

Figure 4. Berlos's SMCR (Sender, Message, Channel, Receiver) Model of Communication is an expansion of the Shannon-Weaver model for communication.

(Source: http://communicationtheory.org/berlos-smcr-model-of-communication)

A third example of this phenomenon is the mathematics and concepts behind the Fitness Landscape, also known by the term Adaptive Landscapes. The concept of fitness landscapes was created to explain phenomena in the field of evolutionary biology but has also been applied to the fields of computer science (via evolutionary optimization programming), robotics, and informing science (by Gill \& Hicks, 2006), anthropology (by Lansing \& Kremer, 1993), operations and production (by McCarthy, 2004), even accounting (by Jermias \& Gani, 2004), to name a few. 


\section{Heterosis and Transdisciplines}

So far, we have examined the spawning of new disciplines through the processes of speciation and heterosis. This paper advances the theory that we can understand the creation of new disciplines by observing them from a "meta" view as elements of transdisciplines.

The term "transdiscipline" has been used to mean different things. We use the term transdiscipline here to denote sets of research models, techniques, and literature that have application across many disciplines and across disciplinary silos. They contain the "genetic" material from various disciplines and can bear fruit across disciplines. In this way, transdisciplines provide robustness to lines of inquiry.

Transdisciplines by their nature have the characteristic of bringing together fields that otherwise appear to have little in common, thereby helping to re-unify science as it was before science was cast into separate silos of knowledge and research traditions in the $19^{\text {th }}$ century. (Stichweh, 2001)

A better term for this would be "meta-discipline" since its goal is to share the best ideas from all constituent disciplines so as to create a coherent whole. But to be consistent with prior uses, this paper will continue to use the term "transdiscipline".

Research within a transdiscipline shares a common goal. That is, the "genetic" material that distinguishes one transdiscipline from another is not just the tools and models it uses but also the specific problem-set it endeavors to solve. In other words, different transdisciplines endeavor to solve different problems.

Let us be clear. Tansdisciplines do not subsume disciplines. That is, each discipline (or parts of it) may "belong to" a variety of transdisciplines. We are not suggesting adding yet one more layer of bureaucracy to academia. Instead, the suggestion is to bring together elements from across diverse fields to yield better science. The focus of each transdiscipline is the solution to its own problem-set, bringing to bear the best discipline specific approaches to the problem.

\section{Case Example: How the transdiscipline "Informing Science" spans disciplinary silos}

The particular focus of the transdiscipline Informing Science is the study of those problems and issues involved with informing clients. Its reference disciplines (from which it draws fundamental models and research) include not only technology-related disciplines (such as computer science and engineering), but also human-focused fields, such as brain science, psychology, and philosophy, to name a few. Its client disciplines include public relations, business, government, and medicine (as they related to the issue of informing their particular clientele). 


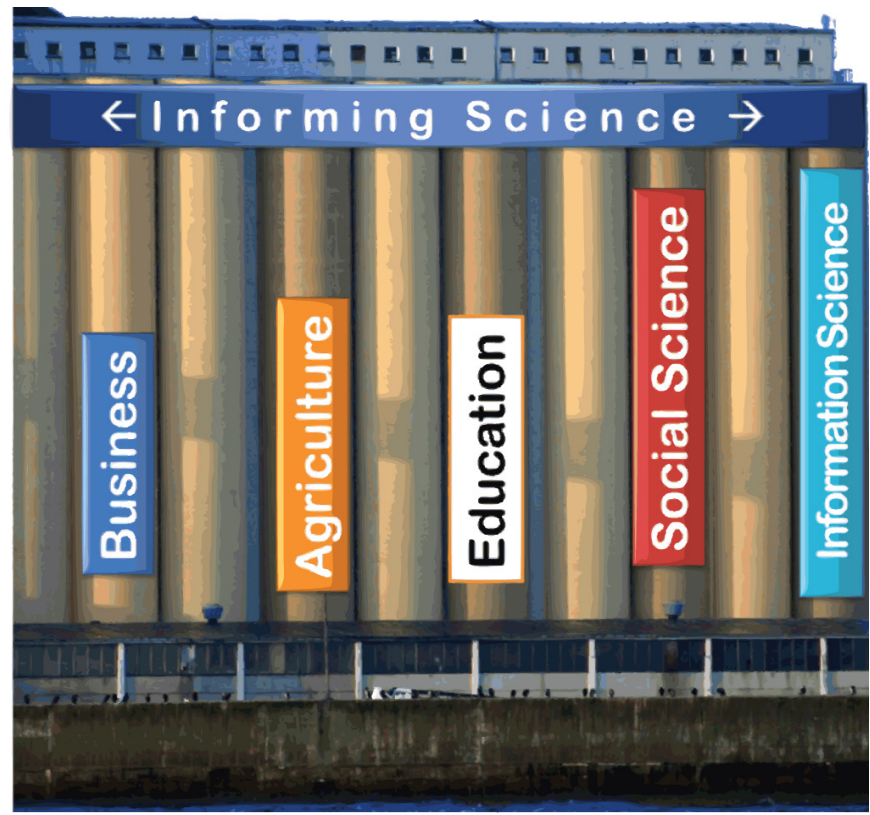

Figure 5. Illustration how a transdiscipline crosses disciplinary silos.

Transdisciplinary research often crosses silos, as illustrated in Figure 5. For example, Cohen (2009) posited a framework that is derived from a combination of work by engineers Claude Shannon and Warren Weaver (1963) (the Shannon-Weaver model of communication) and work in information science by T. D. Wilson (2000). This model is shown as Figure 6.

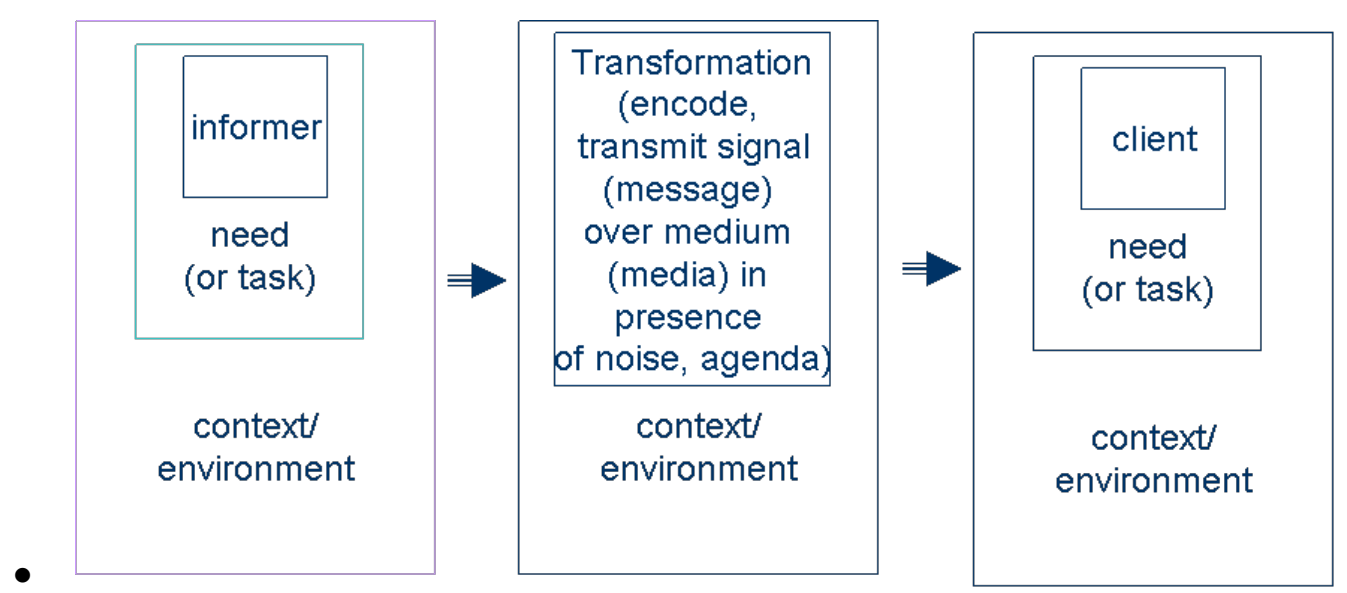

Figure 6. A framework combining models from engineering and information science.

(Source: Cohen, 2009)

Another example, also from Cohen (2009), relates the Shannon-Weaver Communications framework with the work of psychologists Tversky and Kahnemann (1987) on Framing Theory (work that later lead to the award of a Nobel Prize in economics). This model is shown in Figure 7. 

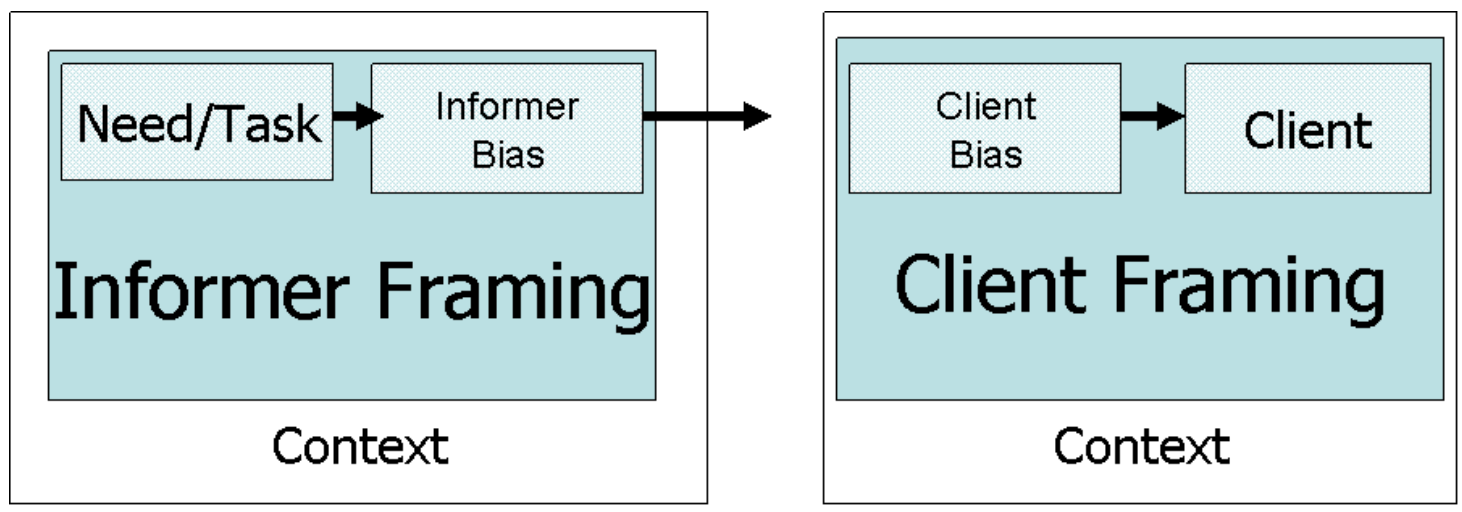

Figure 7. This framework for Informing Science combines the Shannon-Weaver model with Framing Theory (developed for Psychology and applied in economics.

(Source: Cohen, 2009)

It should be obvious that good research theories often cross disciplinary silos, as we saw with the model of Shannon and Weaver that has been applied in a large number of fields. The work of psychologists Tversky and Kahnemann has been applied to economics and, as we see above, to the transdiscipline of Informing Science.

The image that emerges is that the transdiscipline creates new understanding by drawing from the research and research traditions of diverse fields. We have seen from these few examples alone the drawing together of research models and studies that originated in engineering, biology, information science, psychology, and economics to create new understandings of issues related to informing clients.

So far the paper has explored using the framework of evolution to explain how disciplines evolve. The discussion section below deals with the direction in which science is changing.

\section{Discussion}

There are a number of implications to viewing the reality of the modern university from the vantage point illuminated above. First, disciplines are evolving in light of modern technology, in what Biglan (1973a, 1973b) refers to as the hard and applied dimensions. Second, a new form of disciplinary structure is emerging, the transdiscipline. The paper concludes with the recognition that academia needs to train researchers to work as generalists within one or another transdiscipline and to change the reward structure accordingly.

\section{Heterosis of Disciplines toward Biglan's Hard/Applied Quadrant}

Within many disciplines, we see the emergence of new hybrid subdisciplines, the result of mixing in new research from other fields. We saw this earlier that medical imaging developed from medical disciplines combined with imaging research developed in computer science plus technologies developed from research in physics. In general new technologies are developing new areas of research for existing disciplines. This can be seen in Figure 8. 


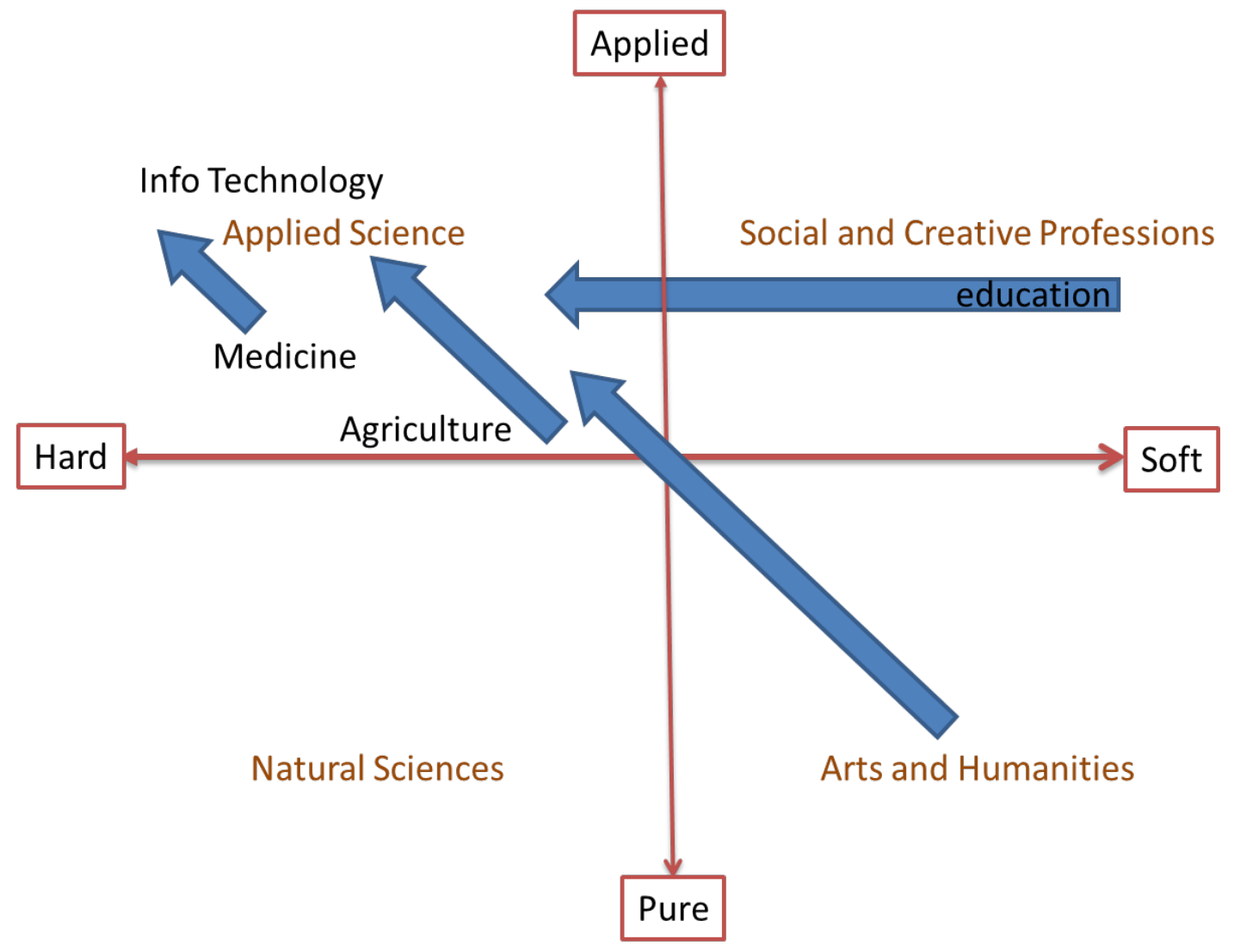

Figure 8: Academic disciplines gain fitness with technology hybridization

\section{Heterosis and Research that Spans Disciplines}

Second, we see the emergence of the transdiscipline that provides research resources that can be applied to a number of disciplines. We discussed the example of Informing Science which provides research findings of use to a variety of disciplines in their search for how best to inform clients. The rise of the transdiscipline is a logical outcome of the need for the various nontechnical disciplines to take advantage of new technologies' ability to add fitness to their research. As we can see in Figure 9, the transdiscipline not only crosses disciplinary silos, it also incorporates areas between these silos, areas that do not fit neatly into any one disciplinary silo. Figure 10 provides evidence of the growing number of research papers that cross outside single disciplinary silos. The figure shows the co-citation network of publications in US journals from 2011 to 2012. This case for the emergence of cross-disciplinary use of research finding is strong, as shown in Figure 10. The highest number of citations per document occurs in multidisciplinary journals. 


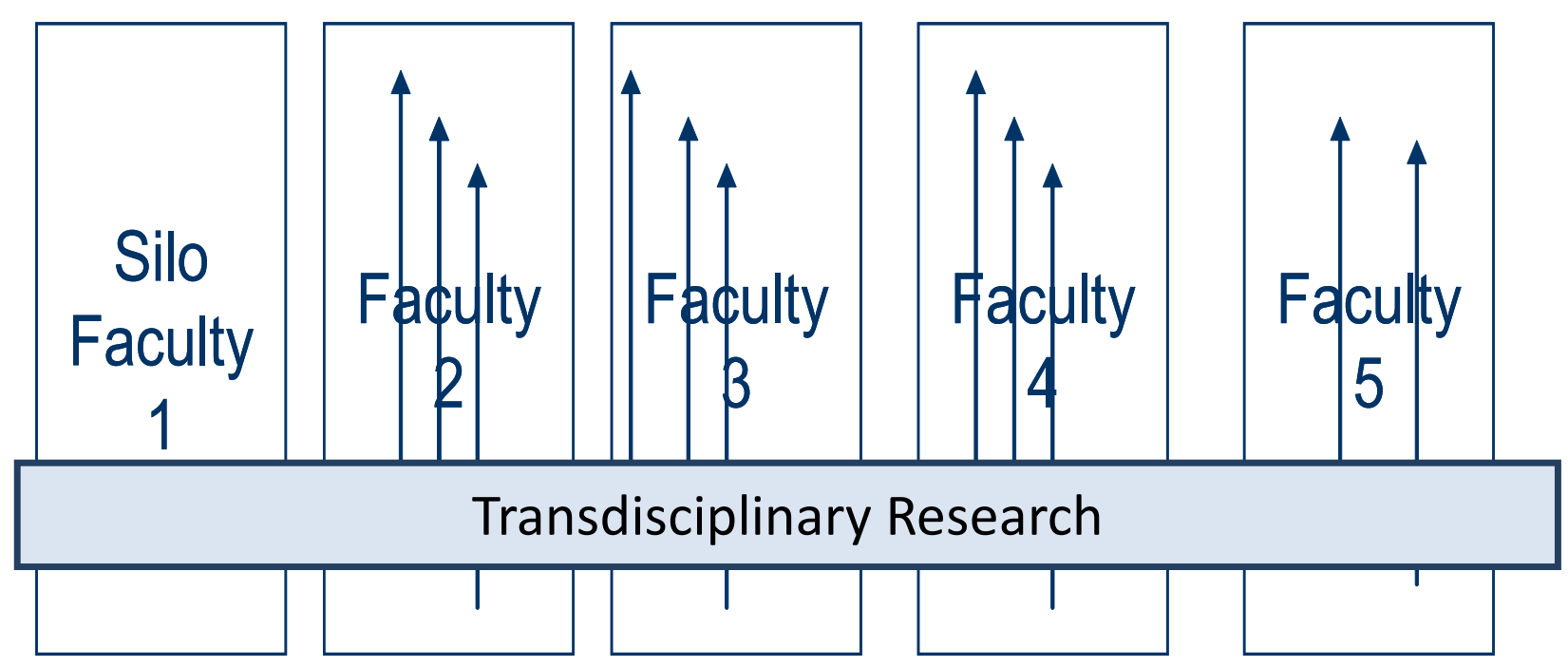

Figure 9. Transdisciplinary Research not only cross disciplinary silos, but also explores areas not covered by any silo.

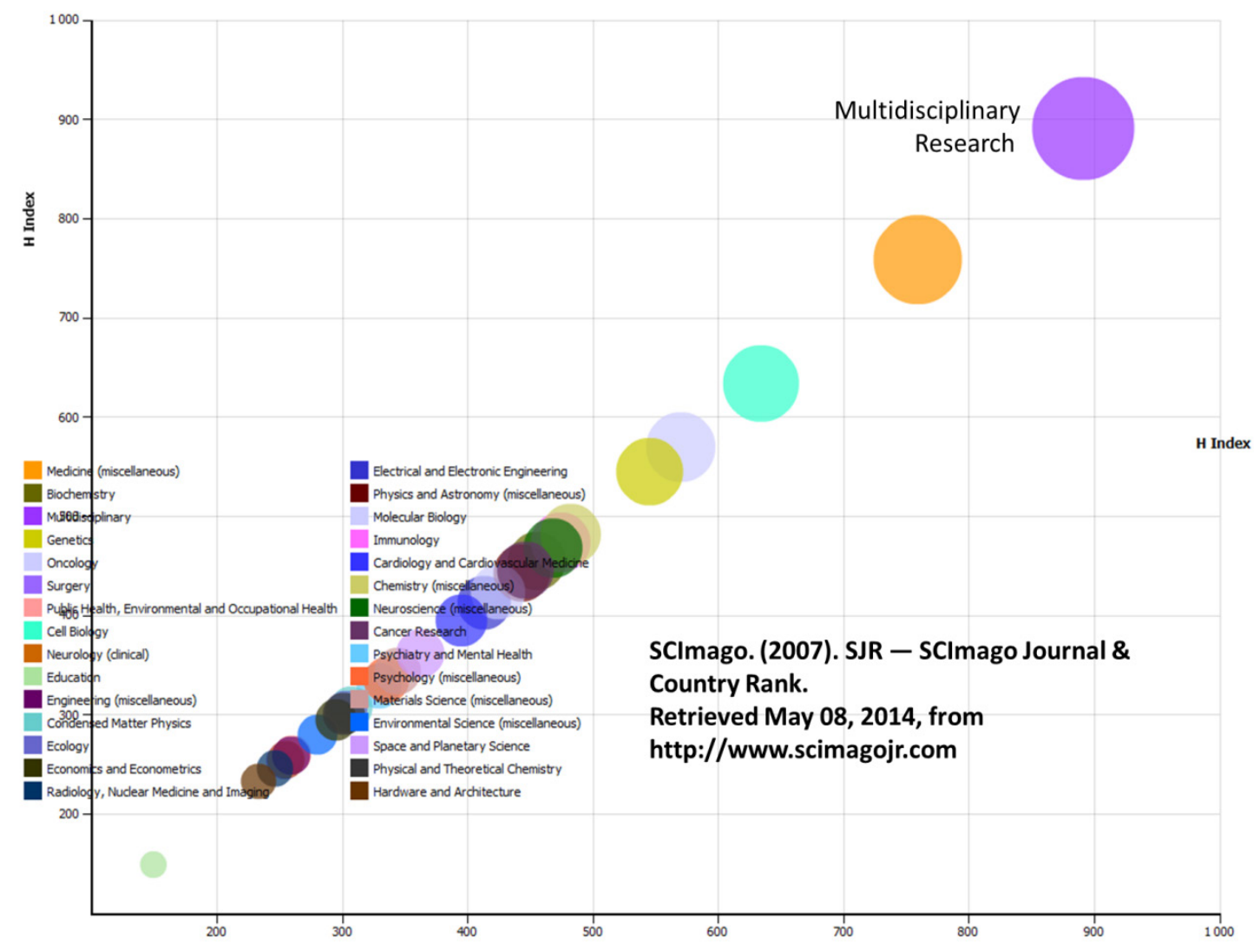

Figure 10. Multidisciplinary journals have the highest h-factor across 30 disciplines for US journals, 2011-2012. (Source: SCImago, 2007). 


\section{Specialists and Generalists}

An implication of these finding is that while we have a plethora of specialists, we need a greater number of research generalists. For example, Don Norman (2011) writes in the web comments of an article by Marc Snir (2011) that "engineering today needs to pay more attention to the psychological, social, political, and economic impacts of its work." Marc Snir (2011) sees a convergence of Computer Science, Information Science, and Engineering.

The convergence goes well beyond computing and engineering. As we have seen, from agriculture to medicine, new areas of inquiry are opening. There is a need for people who are generalists and can work effectively across narrow disciplinary silos. Using Snir's and Norman's examples, society needs computer scientists who are effective in implementing psychological, social, political, and economic elements in their works. And it can well be argued that generalists are nothing more than those investigating from the vantage point of one or another transdiscipline. Waters (2012) goes even farther, writing "our intellectual heroes show us that it pays to be hyphenated", that is, have more than one perspective on nature.

\section{The Need for Cross-Disciplinary Research}

Prior to pointing out the need for academia to reward research that crosses disciplinary boundaries, let us note that the need for cross-disciplinary research is already well founded. Here follows but a small sample of the call for research that transcends disciplinary boundaries.

- E. O. Wilson (1998, p. 8) writes that the most promising path for scientific advancement is the "jumping together of knowledge" across disciplines.

- In brain science, Pellmar and Eisenberg (2000) call for bridging brain, behavioral, and clinical science.

- In medicine and health care (Dauphinée \& Martin, 2000; Gulati (2007)

- In environmental research, Visseren-Hamakers, Gupta, Herold, Peña-Claros, and Vijge (2012) note the need for cross disciplinary borders.

- In women's studies, Allen and Kitch (1998) call for interdisciplinary research.

With industry and so many individual fields calling for research that crosses disciplinary silos, what is standing in the way?

\section{Reform is Needed in Academia, on Campus, and in Journals}

Many universities give interdisciplinary studies only lip service, adopting the interdisciplinary label but not undergoing real reform, according to Rhoten (2004).

Science is related to the pursuit for truth. But "discipline" has two meanings, one of which is "to punish or penalize for the sake of enforcing obedience..." ("Discipline," n.d.)

Academia currently is organized around disciplinary silos, yet many believe that conducting research solely within disciplinary silos stifles the advancement of science. Borrego and Newswander $(2008$, p. 1$)$ note that the "disciplinary department structure of universities is slow to respond to increasingly interdisciplinary problems."

Gazzaniga writes in Science (1998) that the modern university is "partitioned along academic lines that no longer truly reflect today's intellectual life. These academic groupings are now just categories that accountants and business managers use to build a budget."

Goodman and Blake (2006) decry that even in biomedical research, which uses large interdisciplinary teams to answer important scientific questions, academic silos stand in the way. They note that at least some science fields are moving toward solving the silo problem. They write that the focus of the 2006 annual meeting of the Association of Anatomy, Cell Biology and Neurobi- 
ology Chairpersons (AACBNC) was the "Future of Interdisciplinary Research and Training: Breaking Down the Barriers".

Similarly, Rafols, Leydesdorff, O’Hare, Nightingale, and Stirling (2011) found through their scientometric investigation of innovations studies and of business and management that university ranking of journals strictly on the basis of their fit within disciplinary silos suppresses interdisciplinarity.

\section{How Can Universities Move Beyond Silos?}

Pellmar and Eisenberg (2000) note some of the barriers to interdisciplinary research. Some of these barriers are easy to overcome, given the proper leadership.

Using culture and complexity theory Gill (2013) provides an analysis that informs us why there are disciplinary silos. Using his reasoning, the formation of disciplinary silos within universities is inevitable. He writes that the "shared knowledge, beliefs, attitudes and artifacts" that exist within each discipline create its particular culture. And we and our colleagues within our discipline are comfortable once we achieve a localized fitness peak. Using his arguments, the disciplinary silo, with its strong culture, is not inherently bad, but needs to be couples with adaptability.

Gill and Hevner (2013) advance this notion even farther. They apply the concepts of fitness landscape to design and introduce the concept of "design fitness landscape." Using their approach, one would argue that disciplinary silos exist because they once (and perhaps even now) served a very useful purpose. They came into existence and are still here because they provide fitness on the evolutionary fitness landscape.

The problem for universities (and their central administrations) then becomes how to encourage faculty members who are currently at a localized (within discipline) peak to move toward an even higher peak beyond their disciplinary silo? Universities need to make the disciplinary culture more adaptable. For new disciplines, universities might strive to create an environment that disrupts silo formation even before it becomes entrenched. Rewarding transdisciplinary research at a university level might well be a good strategy. At most universities, the only reward structure is set within the individual department. This limits rewards to research which fits cleanly within the artificial boundaries of a discipline. The challenge is to rewards for researchers who work that extends beyond their single discipline. Pellmar and Eisenberg (2000) summarize this best:

"Promotion and tenure policies and practices are major motivators and controlling devices for academic scientists. In a survey of 366 faculty spanning five disciplines in six universities, Moore (1989) found that quality and quantity of publications, followed by grantsmanship, were the most important criteria for tenure but that departmental politics guided all these considerations. It can be difficult, therefore, for junior faculty whose interests range beyond the formal subject matter of a given department to be viewed as either making substantial contributions or as being appropriate for advancement in a given department. ..."

"Interdisciplinary research requires a commitment from university administration. A cross-departmental program can suffer if the administration does not consider the needs for faculty, space, and funds. Through control of faculty positions, the university leadership can promote collaboration, for example, by requiring a position to be jointly supported by two departments (T. Detre, IOM Workshop, 1999) or by ensuring that interdisciplinary programs do not drift back to a primarily single disciplinary perspective (A. Binder, IOM Workshop, 1999)." 
Pellmar and Eisenberg also write of the need for professional organizations that publish transdisciplinary research. The publisher of this paper, the Informing Science Institute, is such one such professional association.

The recognition of the value and need for generalist working on transdisciplinary research is ascending. This paper has shown that in response to technologies, the search for science is evolving toward transdisciplinary approaches to knowledge.

\section{Conclusion}

This paper shows that academic disciplines can be understood the lens of the theory of evolution. It has shown how disciplines mature, develop, and move toward extinction due to changes in the environment. We have seen how the availability of technology, particularly information technology, has had great impact on many disciplines and has led to new disciplines being developed.

The paper demonstrates how science is developing in new ways that cross traditional disciplinary boundaries to such a degree that disciplinary silos can become obstructions. The paper predicts the advancement of new ways of organizing knowledge, around trans-disciplines. The paper suggests that universities learn how to adapt to the change in science by adopting new structures that encourage and reward trans-disciplinary research.

\section{References}

Agriculture. (n.d.) Wikipedia. Retrieved from http://en.wikipedia.org/wiki/Agriculture

Alkan, N. (2008). The importance and influence of philosophical thinking for librarians. Library Philosophy and Practice (e-journal), paper 207. Retrieved from http://digitalcommons.unl.edu/libphilprac/207

Allen, J. A., \& Kitch, S. L. (1998). Disciplined by disciplines? The need for an interdisciplinary research mission in women's studies. Feminist Studies, 24(2), 275-299. Retrieved from http://www.jstor.org/stable/3178698

Alter, S. (2003). Sidestepping the IT artifact, scrapping the IS Silo, and laying claim to "systems in organization". Communications of the Association for Information Systems, 12, 494-526.

American Board of Medical Specialties. (2013). Specialties \& subspecialties. Retrieved from http://www.abms.org/who we help/physicians/specialties.aspx

Anderson, R. I. (1962). Significant implications of research in shorthand and transcription. In D. H. Veon (Ed.), Secretarial education with a future (pp. 49-50). Washington, DC: United Business Education Association.

Antechinus. (n.d.) Wikipedia. Retrieved from http://en.wikipedia.org/wiki/Antechinus

Avison, D. E., \& Nandhakumar, J. (1995, March). The discipline of information systems: Let many flowers bloom! Proceedings of the IFIP International Working Conference on Information System Concepts: Towards a Consolidation of Views (pp. 1-17). Chapman \& Hall.

Benbasat, I., \& Zmud, R. W. (2003). The identity crisis within the IS discipline: Defining and communicating the discipline's core properties. MIS Quarterly, 27(2), 183-194.

Bennett, R. (1988). Time for a new approach to secretarial education. Education + Training, 30(4), 22-25.

Berle, A. A., \& Means, G. C. (1968). The modern corporation and private property (Rev. ed.). Harcourt, Brace and World.

Biglan, A. (1973a). The characteristics of subject matter in different academic areas. Journal of Applied Psychology, 57(3), 195-203.

Biglan, A. (1973b). Relationships between subject matter characteristics and the structure and output of university departments. Journal of Applied Psychology, 57(3), 204-213. 
Bird, B., Welsch, H., Astrachan, J. H., \& Pistrui, D. (2002). Family business research: The evolution of an academic field. Family Business Review, 15, 337-350. doi: 10.1111/j.1741-6248.2002.00337.x

Boholm, Å. (2008). New perspectives on risk communication: Uncertainty in a complex society. Journal of Risk Research, 11(1-2), 1-3.

Borrego, M., \& Newswander, L. K. (2008). Analysis of interdisciplinary faculty job postings by institutional type, rank, and discipline. Journal of the Professoriate, 5(2), 1-31.

Brookes, B. C. (1980). The foundations of information science. Part I. Philosophical aspects. Journal of the American Society for Information Science (pre-1986), 31(4), 125-133.

Cecez-Kecmanovic, D. (2000). The discipline of information systems: Boundaries crossed, boundaries pushed. In M. Sheehan, S. Ramsay, \& J. Patrick (Eds.), Proceedings of the 2000 Conference Transcending Boundaries: Integrating People, Processes and Systems (pp 1-6). Brisbane, Queensland, Australia. Available at http://ecampus.nmit.ac.nz/moodle/file.php/4599/Talent/Sheehan,\%20Ramsay\%20\%20Patrick\%20\%20Transcending_Boundaries, $\% 202000 . p d f$

Cohen, E. B. (1999). From ugly duckling to swan: Reconceptualizing information systems as a field of the discipline informing science. Journal of Computing and Information Technology, 7(3), 213-219.

Cohen, E. B. (2009). A philosophy of informing science. Informing Science: the International Journal of an Emerging Transdiscipline, 12, 1-15. Retrieved from http://www.inform.nu/Articles/Vol12/ISJv12p001-015Cohen399.pdf

CommunicationTheory.org. (n.d.) Berlo's SMCR model of communication. Retrieved from http://communicationtheory.org/berlos-smcr-model-of-communication

Dauphinée, D., \& Martin, J. B. (2000). Breaking down the walls: thoughts on the scholarship of integration. Academic Medicine, 75(9), 881-886.

Discipline. (n.d.) In Merriam-Websters' online dictionary. Retrieved from http://www.merriamwebster.com/dictionary/discipline

Dirks, A. L. (1996). Organization of knowledge: The emergence of academic specialty in America. Retrieved September 18, 2013, from http://webhost.bridgew.edu/adirks/ald/papers/orgknow.htm [This paper originally prepared for HIED 630 History of American Higher Education, Graduate College of Education, Univ. of Mass. Boston.]

Ether Anesthesia. (n.d.). Vat19. Retrieved from http://www.vat19.com/brain-candy/accidental-inventionsether-anesthesia.cfm

Feather, J. (2002). A history of British publishing. Routledge.

Gawande, A. (2012). Two hundred years of surgery. New England Journal of Medicine, 366(18), 17161723.

Gazzaniga, M. S. (1998). How to change the university. Science, 282(5387), 237-237.

Gill, T. G. (2013). Culture, complexity, and informing: How shared beliefs can enhance our search for fitness. Informing Science: The International Journal of an Emerging Transdiscipline, 16, 71-98

Gill, T. G., \& Bhattacherjee, A. (2009). Whom are we informing? Issues and recommendations for MIS research from an informing science perspective. MIS Quarterly, 33(2), 217-235.

Gill, T. G., \& Hevner, A. R. (2013). A fitness-utility model for design science research. ACM Transactions on Management Information Systems (TMIS), 4(2), 5.

Gill, T. G., \& Hicks, R. C. (2006). Task complexity and informing science : A synthesis. Informing Science: the Journal of an Emerging Transdiscipline, 9, 1-13. Retrieved from http://www.inform.nu/Articles/Vo19/v9p001-030Gill46.pdf

Gloeckler, G. (2010, May 6). Best business programs by specialty. Business Week. Retrieved from http://www.businessweek.com/bschools/content/may2010/bs2010055_765866.htm 
Goodman, S. R., \& Blake, C. A. (2006). The future of interdisciplinary research and training: How to conquer the silo guardians. Experimental Biology and Medicine, 231(7), 1189-1191.

Goucher College. (2013). Master of education specializations. Retrieved from http://www.goucher.edu/graduate-programs/graduate-programs-in-education/master-of-education/medareas-of-specializations

Green, J. A. (1905). The educational ideas of Pestalozzi. WB Clive, University Tutorial Press.

Grossman, T. A., Jr. (2001). Causes of the decline of the business school management science course. INFORMS Transactions on Education, 1(2), 51-61. Retrieved from http://archive.ite.journal.informs.org/Vol1No2/Grossman/Grossman.php

Gulati, R. (2007). Silo busting. Harvard business review, 85(5), 98-108.

Hayles, N. K. (2006). Unfinished work from cyborg to cognisphere. Theory, Culture \& Society, 23(7-8), 159-166.

History of education. (n.d.). Wikipedia. Retrieved December 1, 2013, from http://en.wikipedia.org/wiki/History of education

History of surgery. (n.d.). Wikipedia. Retrieved 00:05, December 1, 2013, from http://en.wikipedia.org/w/index.php?title=History of surgery\&oldid $=586087626$

Hook, D., Franks, B., \& Bauer, M. W. (Eds.). (2011). The social psychology of communication. Palgrave Macmillan.

Introduction to evolution. (n.d.) Wikipedia. Retrieved from http://en.wikipedia.org/wiki/Introduction to evolution

Jermias, J., \& Gani, L. (2004). Integrating business strategy, organizational configurations and management accounting systems with business unit effectiveness: A fitness landscape approach. Management Accounting Research, 15(2), 179-200.

Karahanna, E., Davis, G. B., Mukhopadhyay, T., Watson, R. T., \& Weber, R. (2003, December). Embarking on information systems' voyage to self-discovery: Identifying the core of the discipline. In Panel Session at the Twenty-Fourth International Conference on Information Systems, Seattle, Washington (pp. 14-17).

Krishnan, A. (2009). What are academic disciplines? Some observations on the disciplinarity vs. interdisciplinarity Debate. ESRC National Centre for Research Methods. University of Southhampton. Retrieved from http://www.forschungsnetzwerk.at/downloadpub/what are academic disciplines2009.pdf

Kuhn, T. S. (2012). The structure of scientific revolutions. University of Chicago press. https://www.lri.fr/ mbl/Stanford/CS477/papers/Kuhn-SSR-2ndEd.pdf

Lansing, J. S., \& Kremer, J. N. (1993). Emergent properties of Balinese water temple networks: Coadaptation on a rugged fitness landscape. American Anthropologist, 95(1), 97-114.

Large-Scale Agriculture and the Quality of the Social Fabric in Small, Rural Towns in Iowa. (n.d.). Retrieved from http://www.soc.iastate.edu/sapp/LSFarming.html

Library. (n.d.). Wikipedia. Retrieved from http://en.wikipedia.org/wiki/Library

Luskin, B. J. (1970). An identification and examination of obstacles to the development of computer assisted instruction. Doctoral Dissertation, University of California, Los Angeles

Luskin, B. J., \& Friedland, L. (1998). Task force report: Media psychology and new technologies. Washington, DC: Division of Media Psychology, Division 46 of the American Psychological Association. Retrieved from http://www.apa.org/divisions/div46/articles.html

Ma, L. (2012). Meanings of information: The assumptions and research consequences of three foundational LIS theories. Journal of the American Society for Information Science and Technology, 3(4), 716-723 
McCarthy, I. P. (2004). Manufacturing strategy: Understanding the fitness landscape. International Journal of Operations \& Production Management, 24(2), 124-150.

McKeon, M. (1994). The origins of interdisciplinary studies. Eighteenth-Century Studies, 28(1), 17-28.

Media Psychology. (n.d.). Wikipedia. Retrieved from http://en.wikipedia.org/wiki/Media psychology

Models of Communication. (n.d.) Wikipedia. Retrieved from http://en.wikipedia.org/wiki/Models_of_communication

Mutation. (2008). In The American Heritage Medical Dictionary. Houghton Mifflin Company (COR)

Neményi, M., Mesterhazi, P. A., Pecze, Z., \& Stépán, Z. (2003). The role of GIS and GPS in precision farming. Computers and Electronics in Agriculture, 40(1), 45-55.

Norman, D. (2011). [Peer commentary on the article "Computer and information science and engineering: One discipline, many specialties" by M. Snir] Retrieved from http://cacm.acm.org/magazines/2011/3/105328-computer-and-information-science-and-engineeringone-discipline-many-specialties/fulltext

New Media Studies. (n.d.). Wikipedia. Retrieved from http://en.wikipedia.org/wiki/New_media_studies

Orlikowski, W. J., \& Iacono, C. S. (2001). Research commentary: Desperately seeking the "IT" in IT research - A call to theorizing the IT artifact. Information Systems Research, 12(2), 121-134.

Pellmar, T. T. C., \& Eisenberg, L. (Eds.). (2000). Bridging disciplines in the brain, behavioral, and clinical sciences. National Academies Press. Retrieved from http://www.ncbi.nlm.nih.gov/books/NBK44876/

Purdue University. (2012). Graduate student specialties. Retrieved from https://ag.purdue.edu/arp/Pages/Graduate-Student-Specialties.aspx

Rafols, I., Leydesdorff, L., O'Hare, A., Nightingale, P., \& Stirling, A. (2011, September). How rankings can suppress interdisciplinarity. The case of innovation studies and business and management. Atlanta Conference on Science and Innovation Policy 2011. Retrieved Dec. 1, 2013 from http://www.sussex.ac.uk/Users/ir28/IDR/Rafols2011-Rankings\&IDR.pdf

Rhoten, D. (2004). Interdisciplinary research: Trend or transition. Items and Issues, 5(1-2), 6-11.

Saunders, G., \& Lockridge, T. M. (2011). Declining MIS enrollment: The death of the MIS degree? Contemporary Issues in Education Research, 4(1), 15-26)

Schommer-Aikins, M., Duell, O. K., \& Barker, S. (2003). Epistemological beliefs across domains using Biglan's classification of academic disciplines. Research in Higher Education, 44(3), 347-366.

SCImago. (2007). SJR — SCImago Journal \& Country Rank. Retrieved December 09, 2013, from http://www.scimagojr.com

Shannon, C. E. (1948). A mathematical theory of communication. The Bell System Technical Journal, 27(July-August), 379-423, 623-656

Shannon, C. E., \& Weaver, W. (1963). The mathematical theory of communication. Englewood Cliffs, New Jersey: The University of Illinois Press.

Sheth, J. N., \& Parvatiyar, A. (2002). Evolving relationship marketing into a discipline. Journal of Relationship Marketing, 1(1), 3-16.

Silka, L. (2013) "Silos" in the democratization of science. DEMESCI - International Journal of Deliberative Mechanisms in Science, 2(1), 1-14. Retrieved from http://www.hipatiapress.info/hpjournals/index.php/demesci/article/view/742

Snir, M. (2011). Computer and information science and engineering: One discipline, many specialties. Communications of the ACM, 54(3), 38-43. Retrieved from http://cacm.acm.org/magazines/2011/3/105328-computer-and-information-science-and-engineeringone-discipline-many-specialties/fulltext 
Stichweh, R. (2001). Scientific disciplines, History of. In N. J. Smelser \& P. B. Baltes (Eds.), International Encyclopedia of the Social and Behavioral Sciences (pp. 13727-13731). Oxford: Elsevier Science.

Tversky, A., \& Kahneman, D. (1987). Rational choice and the framing of decisions. In R. M. Hogarth \& M. W. Reder (Eds.), Rational choice: The contrast between economics and psychology (pp. 67-94). Chicago: University of Chicago Press

van Gigch, J. P., \& Le Moigne, J. L. (1989). A paradigmatic approach to the discipline of information systems. Behavioral Science, 34(2), 128-147.

van Gigch, J. P., \& Pipino, L. L. (1986). In search of a paradigm for the discipline of information systems. Future Computing Systems, 1(1), 71-97.

Visseren-Hamakers, I. J., Gupta, A., Herold, M., Peña-Claros, M., \& Vijge, M. J. (2012). Will REDD+ work? The need for interdisciplinary research to address key challenges. Current Opinion in Environmental Sustainability, 4(6), 590-596. Retrieved from http://www.colorado.edu/ebio/gradstudents/mischler/CarbonBinder.pdf

Wagner, E. D. (1994). In support of a functional definition of interaction. American Journal of Distance Education, 8(2), 6-29.

Waters, D. J. (2012). The paradox of tethering: Key to unleashing creative excellence in the researcheducation space. Informing Science: the International Journal of an Emerging Transdiscipline, 15, 229-224. Retrieved from http://www.inform.nu/Articles/Vol15/ISJv15p229-245Waters.pdf

Weber, R. (2006). Still desperately seeking the IT artifact. In J. L. King \& K. Lyytinen (Eds.), Information systems: The state of the field (pp. 43-55). John Wiley \& Sons.

Weiss, T. (1992). "Ourselves among others": A new metaphor for business and technical writing. Technical Communication Quarterly, 1(3), 23-36.

Welcome to evolution 101! Understanding evolution. (2014). University of California Museum of Paleontology. Retrieved from http://evolution.berkeley.edu/evolibrary/article/0_0_0/evo_01

Wilson, E. O. (1998). Consilience: The unity of knowledge (No. 31). Random House Digital.

Wilson, T. D. (1981). On user studies and information needs. Journal of Documentation, 37(1), 3-15.

Wilson, T. D. (1999). Models in information behavior research. Journal of Documentation, 55(3), 249-270. Retrieved December 1, 2008, from http://informationr.net/tdw/publ/papers/1999JDoc.html

Wilson, T.D. (2000). Human information behavior. Informing Science: the International Journal of an Emerging Transdiscipline. 3(2), 49-56. Retrieved December 1, 2008, from http://inform.nu/Articles/Vol3/v3n2p49-56.pdf

\section{Biographies}

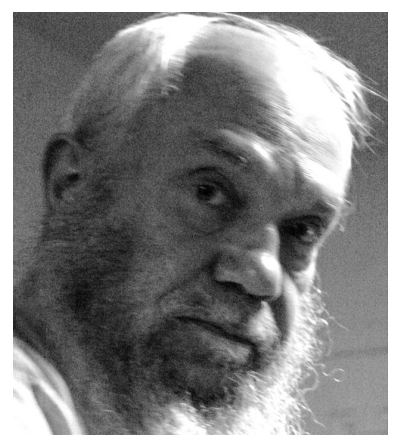

Eli Cohen is the founder of and serves as an executive director and governor of the Informing Science Institute. He has a multidisciplinary background in psychology, information systems, statistics, and education. He served as a professor at the Kozminski University from shortly after its founding until his retirement. 


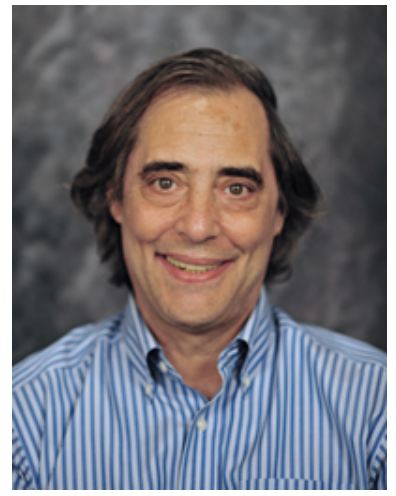

Scott J. Lloyd, Ph.D. is an Assistant Professor of MIS at The University of Rhode Island and received his Ph.D. in Management Information Systems from Kent State University. He teaches in the area of databases, Informing sciences, knowledge management and system design. Dr. Lloyd has had his research published in The Journal of Database Management, Industrial Management, Midwest Decision Sciences Proceedings, Simulators International and Modeling and Simulation. He serves on the Editorial board of The Journal of Database Management and as associate editor of The Journal of Electronic Commerce in Organizations. He has been Track Chair of Computers and Information Systems for North East Decision Science Proceedings. Since his appointment to the URI faculty he has published in Industrial Mathematics, Software Engineering in the 21st Century, Journal of Electronic Commerce in Organizations, North East Decision Sciences Proceedings, National Decision Science Proceedings and Information Resources Management Association National Proceedings and was the co-editor of Software Engineering in the 21st Century. Lloyd also has worked in industry as an MIS consultant, DBA and research technologist. His current research has expanded to include Informing Sciences and how to best facilitate improving the transfer of knowledge. 